DOI: https://doi.org/10.18485/philologia.2020.18.18.12

UDC: 811'276.6:355

\title{
CONTEXTING THE TRANSLATION OF MILITARY TEXTS
}

VERONA-ELENA POPA (CIOCIOI) ${ }^{1}$

University of Craiova

Craiova, Romania

U radu se analiziraju teškoće koje se javljaju u prevođenju vojnih tekstova, uzimajući u obzir specifičnosti vojne terminologije. Opsežna istraživanja na polju translatologije pokazala su da u stručnom prevođenju veliku ulogu ima prevodilac i da takvo prevođenje zahteva nove pristupe. Razmatraju se dve nedoumice: jedna $u$ vezi s prisustvom i funkcijom metafore $u$ vojnom diskursu, i druga koja se tiče uticaja stručnosti prevodioca na kvalitet prevoda.

Ključne reči: kontekst, metafora, vojna terminologija, prevod.

\section{INTRODUCTION}

Are solid knowledge of the target language and excellent command of the source language enough in order to produce a professional translation? These are paramount prerequisites but they are not sufficient to carry out such a challenging task as producing an accurate and readable translation. Knowledge of the field subject is a must. It would be tempting to assume that English, "as the lingua franca of translation" (Anderman and Rogers 2003: 1), has made the world of translation easier and more accessible, nevertheless, we consider that globalisation has turned this task into a greater responsibility. Can global communication function beyond translation? Besides, some (sub)fields of translation might be considered more accessible than others based on the assumption that they are highly technical, hence more easily subjected to the translation phenomenon. Military texts might be perceived as falling under this category, since they share some common characteristics, such as making use of military terminology, abbreviations and non-figurative language.

Admittedly, we set out to provide answers to the following research questions: Are military texts/speeches dry and devoid of metaphoric language? Are military texts/ speeches easier to translate than other types of texts since they are seen as highly

1 Kontakt podaci (Email): verona_popa@yahoo.com 
technical texts that make use of non-figurative language? What are the problems that a translator comes across when translating a military text? What are the functions that metaphors fulfil in a specialised text and does their presence make the text more translation resistant? Is the translation of military texts the realm of a highly-specialised military translator? And how has the role of the translator changed in recent years?

\section{THE CHALLENGES OF MILITARY TEXTS}

It is true that for a layman military texts seem to be poor in metaphoric language, yet history abounds in beautifully-written military speeches that made hearts beat faster and encouraged soldiers in battles. In this respect, we have chosen five excerpts that reveal the presence of skilful artistic expressions. The analysis of military texts cannot be produced outside an understanding of the concept of discourse. Derived from the Latin discursus, "running to and fro", the word discourse denotes written and spoken communication modes; in semantics and discourse analysis, discourse is "the totality of codified linguistic usages attached to a given type of social practice, e.g. legal, medical, religious discourse".?

The military discourse, which plays an integral role in a conflict, has a life and force of its own. In Makers of Modern Strategy, Shy and Collier state that "Language is used to isolate and confuse enemies, rally and motivate friends, and enlist the support of wavering bystanders." (Shy and Collier 1986: 821) Words can be powerful weapons, since there is a strong relationship between language and the context in which it is used. The military discourse is worth being analysed from a social, historical, cultural but also a linguistic perspective.

\subsection{COMMON FEATURES OF MILITARY SPEECHES}

The excerpts selected for a linguistic analysis run as follows:

- Queen Elizabeth I's speech - "Against the Spanish Armada" - a landmark of military speeches that Queen Elizabeth delivered when she visited her troops who were preparing for the battle against the Spanish Armada;

- Abraham Lincoln's speech - "The Gettysburg Address" - which, in spite of containing only 272 words, is one of the most impressive pieces of rhetoric in American history;

- Winston Churchill's speech - "We Shall Fight on the Beaches" - delivered on the 4th of June 1940 to the House of Commons of the Parliament of the United Kingdom. The Peroration can be considered a masterpiece of rhetoric;

- Franklin D. Roosevelt's speech - "Pearl Harbour Address to the Nation" - in which the President declares War on Japan after the attack on Pearl Harbour;

- Colonel Tim Collins' speech - delivered to the $1^{\text {st }}$ Battalion of the Royal Irish Regiment in Iraq in 2003.

2 http://www.revuetexto.net/Reperes/Glossaires/Glossaire_en.ht 
These speeches are refined examples of rhetoric that when first uttered stirred the emotions of listeners, and continue to excite their readership and appeal to the mastery of the translator. Translation is an art and a skill, deeply rooted in scientific concepts and terminology. It starts from key concepts, theories and paradigms to lead to the recreation of the original. In other words, it underpins a framework containing the basic assumptions and methodology that are commonly accepted by the members of a community of practice. According to mainstream literature, Translation Studies has witnessed many kinds of turns or paradigms that shift from linguistic to culture and recently to technology (notably, Snell-Hornby; 2006; Cronin 2010).

Basically, three paradigms are attributed to translation: the linguistic paradigm, the cultural paradigm and the social and psychological paradigm. Whatever the approach, nowadays, it is difficult to imagine the translation process outside any of these paradigms as each involves and uses the others.

Owing to different factors, among which the cultural and the historical context, translation has been viewed and defined as a research-oriented process. Although translation has definitely turned into a science, it is undeniable that it was initially studied as a linguistic phenomenon. Our approach proposes the linguistic paradigm as a useful starting point of the translation process, taking into consideration the fact that the texts subject to analysis are extremely rich in language-related issues, which are recurrent in the practice of translation. According to Catford (1965), it is unreasonable to study translation outside its relationship to linguistics.

In what follows, we shall identify a number of common features of the military speeches selected for analysis. All the excerpts contain technical vocabulary, related to the battlefield and war: air squadrons, armed attack, armed, battle, battlefield, bombing, camp, campaign, casualties, coalition, commander-in-chief of the Army and Navy, comrades, defend, field, fight, fleet, invade/invasion, launched an attack, lieutenant general, naval and air forces, offensive, raids, regiment, stratagem, surrender, take up arms, torpedoed, uniform, victory, war.

Moreover, the sample speeches make use of powerful words - adjectives, adverbs and adverbial phrases abound in the aforementioned speeches: absolute, ancient, brave, brutal, dastardly, faithful, ferocious, foremost, honoured, inevitable, loving, magnanimous, noble, odious, outlandish, premeditated, righteous, rightful, steady, treacherous, unbounding, unprovoked, upright, worthy; (defend) to the death, (defend) to the uttermost, (fight) with growing confidence, deliberately, duly, generally, highly, lightly, needlessly, nobly, properly, shortly.

It is interesting to note the frequency of these words; for instance, the word nation appears five times in Abraham Lincoln's speech, the word people is mentioned four times and the word dedicate(d) is used six times in Abraham Lincoln's speech. Winston Churchill uses we shall fourteen times in his powerful speech. The word deliberately is repeated three times by Franklin D. Roosevelt, whereas Colonel Tim Collins mentions the word alive three times in his speech.

Another interesting feature is the recurrence of the personal pronoun we, which is used as follows: in Queen Elizabeth I's speech - nine times; in Abraham Lincoln's speech - ten times; in Winston Churchill's speech - eighteen times; in Franklin D. Roosevelt's 
speech - twice; in Colonel Tim Collins' speech - twelve times. It is used to express a sense of belonging, of shared responsibility.

The associations of synonyms or similar words indicates the presence of metaphoric language in these highly technical texts: with all its power and might; stratagem and ... manoeuvre; to the rescue and the liberation of ...; the very life and safety of our nation; no threat or hint of war; with confidence... with the unbounding determination; strength and safeguard; in the midst and the heat of the battle.

Basically, conversation is intended to facilitate communication, and although people have a tendency to associate metaphoric language with written communication and poetic writings, it is not unusual for people to use metaphors and figures of speech both in informal written and oral messages:

Many metaphors are "off-loaded" into the cultural world to enable people to better solve problems, make decisions, and perform skilled action in the exact same way that having paper and pencil and abacuses allows us to do complex arithmetic. [...] People talk about their emotional experiences in metaphorical terms based on their interactions with real-world objects that take on symbolic character. (Gibbs 1997: 157-158)

Another factor that contributes to metaphor variation is the discourse contexts in which it is used. Furthermore, certain written registers display a much greater density of metaphor use than others.

There are instances of metaphoric language in all the sample speeches. Queen Elizabeth states: I come amongst you ... in the midst and heat of the battle; the body of a weak, feeble woman ... the heart and stomach of a king; rewarder of every one of your virtues in the field; for your forwardness you have deserved rewards and crowns; Abraham Lincoln also relies on metaphoric language: our fathers brought forth ... a new nation; testing whether that nation ... can long endure; that cause for which they gave the last full measure of devotion; a new birth of freedom; Winston Churchill resorts to figures of speech throughout his speech: an absolute guarantee against invasion; In the days of Napoleon, of which I was speaking just now, the same wind which would have carried his transports across the Channel might have driven away the blockading fleet; It is that chance which has excited and befooled the imaginations of many Continental tyrants; the originality of malice, the ingenuity of aggression; to ride out the storm of war; the New World, with all its power and might, steps forth to the rescue and the liberation of the old. President Roosevelt uses metaphors to lend more force to his patriotic speech: a date which will live in infamy; The facts of yesterday and today speak for themselves; this form of treachery shall never again endanger us; our interests are in grave danger; we will gain the inevitable triumph. So does Colonel Tim Collins to emphasise the idea of freedom and liberation: I expect you to rock their world; It is the site of the Garden of Eden, of the Great Flood and the birthplace of Abraham; the light of liberation; stains on their souls and they are stoking the fires of hell; the mark of Cain upon them; your deeds will follow you down through history.

It is obvious that military speeches are not devoid of figures of speech, that they contain original associations of words and compelling metaphors. This is not surprising 
since metaphors are powerful tools that reveal people's ideas and thoughts and make the speech dynamics more vivid. Moreover, military speeches belong to the category of vocative texts and their main purpose is to persuade or to manipulate the intended audience. Does the fact that there is an immediate implicit relationship between the writer and the readership make them more easily translatable? One of the challenges of producing a good translation is to find suitable equivalents for the metaphoric expressions.

An influential theory has proposed that "metaphor is for most people a device of the poetic imagination and the rhetorical flourish - a matter of extraordinary rather than ordinary language." (Lakoff and Johnson 1980: 8) The authors consider that "human thought processes are largely metaphorical. This is what we mean when we say that the human conceptual system is metaphorically structured and defined. Metaphors as linguistic expressions are possible precisely because there are metaphors in a person's conceptual system." (ibid. 10)

\subsection{THE TASK OF THE TRANSLATOR}

Although they come natural in thought and speech, metaphors do not make the translation easier. On the contrary, they represent a challenge since a translation is not just a rewriting of the original text. It implies much more than a simple rendering of the source language text into the target language text. The translator comes across many difficulties and he/she has to come up with solutions, credible solutions.

The translation process is laborious work since the translator has to de-construct or to de-contextualise the original text and to re-contextualise it all over again. We shall enumerate some of the difficulties that the translator will have to deal with when translating the above-mentioned texts.

One of them is getting to know the context. To put it simply, translation means carrying meaning from the source language to the target language. But a text cannot exist out of the context and the culture in which it is produced. Working with language involves acting. Language is a linguistic as well as a social tool.

The attempt to go beyond the mere replacement of words in translation underpins the topicalisation of the social nature of language: to use language is to perform an action. Language is a tool to represent, present reality and act upon reality in interaction with others. [...] The language-culture connection has long become axiomatic no matter the level we take into consideration, i.e. intralingual or interlingual. (Vîlceanu 2018: 13)

Therefore, in order to understand a text and to produce a credible translation, the translator has to analyse the background, the context in which the original text was produced. Language is a part of the culture and the context in which it is produced. The context can be understood in terms of historical context, cultural context, social context, linguistic context.

Further on, we shall be focusing on the linguistic context. Words interact with other words in order to form a meaningful text, but they also change their usage. One of the challenges might be to render a suitable translation for those words that have 
changed their meaning / frequency of usage over the years. Throughout the sample speeches, there are examples of words whose frequency of usage has lowered over the years or words whose meanings have changed over the years or have acquired a different predominant occurrence.

Besides, there is the challenge posed by culture-specific items - those concepts specific for a certain culture. Queen Elizabeth I speaks of her lieutenant general, which, given the historical period in which the speech was delivered and the different ranks in the British and the Romanian armies might be translated as comandantul meu de oști. Terms related to the military domain could be translated using different strategies, of which we shall mention dynamic equivalence and domestication. We adopt the concept of dynamic equivalence as defined by Nida (1964) in his far-reaching work Toward a Science of Translating, i.e. the re-creation of the relationship between the original receptors and the message.

Enlarging the perspective by focusing on cultural aspects, Newmark (1988) points out to different translation procedures applied for culture-specific items: transference, cultural equivalent, neutralisation (i.e. functional and descriptive equivalent), literal translation, label, naturalisation, componential analysis, deletion, couplet, recognized translation, paraphrase, gloss, notes, etc., and classifier. Although transference and literal translation would seem the most convenient procedures, translation should by no means be restricted to one procedure only. Since any act of translation is also a decision-making process, translators have their say: It is a big step to take another human life might be rendered in different ways, but they all emphasise the idea of assumption and of responsibility: este o responsabilitate uriașă să iei o altă viață omenească or nu este ușor / este o decizie grea să iei viața altcuiva.

The intended purpose is to give coherence and significance to the newly resulted text, starting from the translation of individual words and single units and resulting in a meaningfully assembled target language. Newmark himself favours neither literal translation nor an exaggerated version of the original.

Also from an integrated perspective, Venuti endorses two main strategies for handling translation and achieving the translator's invisibility:

- domestication - the process through which the translator produces "an idiomatic and 'readable' target text". For instance, the structure commanders who have stains on their souls does not have a perfect equivalent into Romanian and a literal translation would seen unnatural. The same image might be converted into conștiința murdară.

- foreignization - the exclusion of dominant cultural elements. In translating the structure I interpret the will of the Congress, the translator might deliberately opt for preserving the literal equivalent of Congress, as no other word would render the exact meaning. One solution of optimal compromise would be to add the word American.

The translation process is a deliberate one, therefore domestication leads to a greater degree of fluency, thus rendering the "effect of transparency, the illusion that this is not a translation" (Venuti 1995: 61). Although foreignization is envisaged as a more subjective strategy, it is sometimes necessary as subjectivity itself is determined by social and cultural factors.

In our corpus, we may identify several culture-specific items: lieutenant general; ... his transports across the Channel might have driven away the blockading fleet; the resolve 
of His Majesty's Government; Mr. Vice President, Mr. Speaker, Members of the Senate, and of the House of Representatives; Commander in Chief of the Army and Navy.

At the aesthetic level, another recurrent challenge for the translator might be the presence of repetitions as powerful rhetoric devices. As a stylistic figure, repetition relies upon the presence of one or more identical or equivalent elements in the same context. In military speeches, in particular, repetitions are important to reinforce meaning, to give strength to communication, which raises some important questions: Should repetitions be kept in the translation process? Do repetitions reduce or enhance the meaning of the translation? Although the translator has no constraints (other than the professional or ethical constraints) when it comes to choosing what to translate and how to translate, we would recommend keeping repetitions in the source language, as it can help convey essential elements. In addition, it is preferable to keep a balance between an intuitive translation and a faithful one.

It is very important for a translator to "dissect language" because s/he needs to grasp the nuances, the subtleties of the text to be translated, $s /$ he needs to research terminology, neologisms, archaisms, handle changes in language but also master the field of the required translation. The role of the translator is crucial yet "shadowy".

Examining the language of military speeches could provide useful insights into the nature and the context in which the speeches were delivered and also help the translator decide upon the translation strategies to be used.

Even if the translator of a military text is not an expert in the military field, it is obvious that $\mathrm{s} /$ he needs a high degree of thematic competence. However, thematic competence is not sufficient, it works hand in hand with linguistic competence and with many other disciplines. Therefore, a translator needs to be open to an interdisciplinary approach by combining elements from areas such as linguistics, rhetoric, hermeneutics, translation studies, functional stylistics, cultural studies, etc.

The translator of a military text faces the double challenge of dealing with metaphoric subtleties and of producing an accurate translation given the technical dimension of these documents.

\section{CONCLUSION}

Military speeches can be considered powerful tools of rhetoric and it would be unjust to consider them dry or tedious. When analysed in detail, they can provide interesting information at a linguistic, historical, social and cultural level. Found at the intersection of technical and literary language, the speeches selected for analysis allow for a comprehensive analysis in terms of metaphor identification and translation. They are meant to make communication efficient by appealing to clarity and coherence, but also persuasive by appealing to figurative language and numerous figures of speech. Although a microanalysis of military speeches reveals the fact that they do share some common linguistic features, such as powerful words, repetitive units or figurative language exaggerated in a deliberate way, the translation of military discourse requires knowledge of the field and an understanding of the context and the circumstances in which the speech was delivered. However, the translation of metaphors in military 
speech is neither easier nor more difficult than the translation of metaphors in other contexts. It requires mastery of the translation procedures and techniques and a thorough comprehension of the original text since the translator becomes the decisionmaking factor as to what to change or leave out. Leaving out or adding information should not impede clarity or interfere with the persuasive function of metaphoric language, which, in military speeches, is unquestionably used to persuade and stir emotions. Although specialised language is not effortless to be dealt with, we strongly recommend keeping the metaphorical meaning, which plays as equally an important role as technical language in the algorithm of translation. In spite of not being a highly specialised military expert, it is the duty of the translator to identify metaphoric language and to provide a suitable translation that has to render the aesthetic value and the technical accuracy of the texts subject to translation.

\section{REFERENCES}

Anderman, G. and M. Rogers. 2003. Introduction. In G. Anderman and M. Rogers (eds.) Translation Today - Trends and Perspectives. London: Multilingual Matters, 1-12. Catford, J. C. 1965. A Linguistic Theory of Translation. London: OUP. Cronin, M. 2010. The Translation Crowd. Traducció i la Communicació 8, 1-7.

Gibbs, R. W., Jr. 1997. Making Metaphor out of Our Heads and Putting It into the Cultural World. In R. W. Gibbs Jr. and G. J. Steen (eds.) Metaphor in Cognitive Linguistics. Amsterdam and Philadelphia: John Benjamins Publishing Company, 145-166.

Lakoff, G. and M. Johnson. 1980. Metaphors We Live by. London: The University of Chicago Press.

Newmark, P. 1988. A Textbook of Translation. London: Prentice Hall International. Nida, E. A. 1964. Toward a Science of Translating. Leiden: E. J. Brill.

Shy, J. and T. W. Collier. 1986. Revolutionary War. In P. Paret (ed.) Makers of Modem Strategy from Machiavelli to the Nuclear Age. Princeton, New Jersey: Princeton UP, 815-62.

Snell-Hornby, M. 2006. The Turns of Translation Studies. Amsterdam and Philadelphia: John Benjamins Publishing Company.

Venuti, L. 1995. The Translator's Invisibility. A History of Translation. London: Routledge. Vîlceanu, T. 2018. Loss in Translation? Bilingual Synonymy and Cultural Intertraffic. Beyond Words and into the Message. Building Communication across Languages, Media and Profession. București: Conspress, 11-28.

\section{ELECTRONIC SOURCES}

http://www.bl.uk/learning/timeline/item102878.html [accessed August 5, 2019]. http://www.abrahamlincolnonline.org/lincoln/speeches/gettysburg.htm [accessed August 9, 2019].

https://winstonchurchill.org/resources/speeches/1940-the-finest-hour/we-shall-fighton-the-beaches/ [accessed August 10, 2019]. 
http://www.historyplace.com/speeches/fdr-infamy.htm [accessed September 12, 2019]. https://www.telegraph.co.uk/comment/3562917/Colonel-Tim-Collins-Iraq-warspeech-in-full.html [accessed September 13, 2019].

\section{SUMMARY}

\section{CONTEXTING THE TRANSLATION OF MILITARY TEXTS}

The aim of this paper is to put a spotlight on the challenges related to the translation of military texts, starting from idiosyncratic features associated with military terminology. Extensive research in the field of translation has led to new approaches regarding both the role of the translator and the way translation is envisaged. The questions to delve into are twofold: on the one hand, to determine the presence and the functions of metaphoric language in military discourse and, on the other hand, to establish the extent to which specialised translation is the hallmark of professionals certified in the corresponding field.

KEYWORDS: context, metaphor, military terminology, translation.

ARTICLE INFO:

Original research article

Received: April 1, 2020

Revised: October 4, 2020

Accepted: November 2, 2020 